\title{
ADSORPTION OF Mg(II) AND Ca(II) ON DISULFONATO-SILICA HYBRID
}

\author{
Choiril Azmiyawati ${ }^{1,2,}$, Nuryono $^{2}$, and Narsito ${ }^{2}$ \\ ${ }^{1}$ Department of Chemistry, Universitas Diponegoro, Jl. Prof. Soedarto, Tembalang, Semarang, Indonesia \\ ${ }^{2}$ Department of Chemistry, Faculty of Mathematics and Natural Sciences, Universitas Gadjah Mada, \\ Sekip Utara, Yogyakarta, Indonesia, 55281
}

Received August 1, 2012; Accepted October 22, 2012

\begin{abstract}
Adsorption of $\mathrm{Mg}(\mathrm{II})$ and $\mathrm{Ca}(\mathrm{II})$ on disulfonato-silica hybrid (DSSH) in the aqueous solution has been studied. The hybrid was synthesized by sol-gel process with sodium silicate solution from rice hull ash, chloroprophyltrimethoxysilane (CTS) and 4-amino-5-hydroxy-naphtalene-2,7-disulfonic acid monosodium salt (ANSNa) as silica source, cross linker and active group, respectively. Sodium silicate solution was reacted with CTS and ANSNa that were added dropwise. Adsorption of magnesium and calcium ions on DSSH was carried out in a batch system. Solution $\mathrm{pH}$ significantly affected magnesium and calcium adsorption and the optimum condition was obtained at $\mathrm{pH}=6$. The synthesized DSSH showed a high adsorption capacity of $0.0844 \mathrm{mmol} / \mathrm{g}$ and $0.1442 \mathrm{mmol} / \mathrm{g}$ for $\mathrm{Mg}(\mathrm{II})$ and $\mathrm{Ca}(\mathrm{II})$, respectively. The adsorption isotherm obtained with Langmuir isotherm model gives the negative values of $\Delta G^{\circ}$, i.e. $-23.334 \mathrm{~kJ} / \mathrm{mol}$ and $-22.757 \mathrm{~kJ} / \mathrm{mol}$ for $\mathrm{Mg}(\mathrm{II})$ and $\mathrm{Ca}(\mathrm{II})$, respectively, indicating the spontaneous process of adsorption. Kinetic studies showed that the adsorption of $\mathrm{Mg}(\mathrm{II})$ and $\mathrm{Ca}(\mathrm{II})$ ions onto HDSS follows the pseudo-second-order kinetics.
\end{abstract}

Keywords: adsorption; silica; magnesium; calcium; sulfonate

\section{ABSTRAK}

Adsorpsi Mg(II) dan Ca(II) pada hibrida disulfonato-silica (DSSH) dalam larutan telah dipelajari. Hibrida disintesis melalui proses sol-gel dengan natrium silikat dari abu sekam padi, kloropropiltrimetoksisilan (CTS), dan garam mononatrium asam 4-amino-5-hidroksi,2-7-naftalenadisulfonat (ANSNa) berturut-turut sebagai sumber silika, pengait silang, dan gugus aktif. Larutan natrium silikat yang diperoleh dari abu sekam padi direaksikan dengan natrium hidroksida, kemudian ditambahkan CTS dan ANSNa secara bertetes-tetes. Adsorpsi magnesium dan kalsium pada DSSH diuji menggunakan sistem batch. Nilai $\mathrm{pH}$ larutan secara nyata berpengaruh terhadap adsorpsi $\mathrm{Mg}(\mathrm{II})$ dan $\mathrm{Ca}(\mathrm{II})$ dan kondisi optimum diperoleh pada $\mathrm{pH}=6$. DSSH hasil sintesis memperlihatkan kapasitas adsorpsi yang tinggi yaitu sebesar 0,0844 mmol/g dan 0,1442 mmol/g berturut-turut untuk $\mathrm{Mg}(\mathrm{II})$ dan Ca(II). Isoterm adsorpsi diperoleh dengan model Langmuir memberikan nilai $\Delta G$ negatif, yaitu $-23,334 \mathrm{~kJ} / \mathrm{mol}$ untuk $M g(I I)$ dan $-22,757 \mathrm{~kJ} / \mathrm{mol}$ untuk $\mathrm{Ca}(\mathrm{II})$, yang menunjukkan adsorpsi berlangsung spontan. Dari kajian kinetika ditunjukkan bahwa adsorpsi ion $\mathrm{Mg}(\mathrm{II})$ dan Ca(II) mengikuti kinetika pseudo orde-kedua.

Kata Kunci: adsorpsi; magnesium; kalsium, silika, sulfonat

\section{INTRODUCTION}

Recent studies of adsorption have demonstrated that solid substrate of silica materials is able to adsorb $\mathrm{Mg}$ ion from industrial effluents, natural water, and sea water [1]. Adsorption of magnesium and calcium ions is rarely studied, because these ions are not the common and toxic pollutants released into the natural waters from various industrial activities. Nevertheless, these ions can increase the hardness of water [2].

The investigation of adsorbent has been focused on synthesis and application. Sulfonato silica can be formed by grafting method [3-4]. Researches about sol-

* Corresponding author. Tel/Fax : +62-8157904691

Email address : cazmiyawati@yahoo.com

gel method besides the grafting one have been reported, i.e. preparing sulphonated-silica (ormosil) hydrogels [5], polyacrylate silica nanocomposite [6], and the hexagonal mesoporous silica modified with 2-mercaptothiazoline [7]. The sol-gel method has special quality, because the formation of bonding at sol process. Therefore, in this study the formation of sulfonato silica was done using sol-gel method.

Nevertheless, sulfonic functionalized silica was obtained by bonding thiol group and then was oxidation by hydrogen peroxide. The sulfonic acid functionalized silica can be used as an efficient heterogeneous catalyst for a three-component synthesis of 
1,4-dihydropyridins under solvent-free conditions [8]. They have developed an useful method for the synthesis of 1,4-dihydropyridins using sulfonic acid functionalized silica as an efficient catalyst. The mild, heterogeneous and solvent-free conditions, short reaction time, high yields, operational simplicity and reusability of the catalyst are the notable advantages of the protocol.

The common methods for separation of magnesium and calcium ions are electrolysis and adsorption. In this paper we report the application of disulfonato-silica hybrid (DSSH) adsorbent for adsorption of magnesium and calcium ions in aqueous solution. The adsorbent contains active site (- $\mathrm{O}^{-}$groups) on the sulfonate group that it may bond cations. A batch system is used in this experiment to evaluate parameters of the adsorption. The DSSH was synthesized through sol-gel method and the sulfonic functionalized silica was obtained by bonding sulfonate group from 4-amino-5-hydroxy-naphtalene-2,7-disulfonic acid monosodium salt (ANSNa) on silica gel through cross-linking of chloroprophyltrimethoxysilane (CTS). The existence of sulfonate groups on the DSSH has a greater ability to bind metal cations such as $\mathrm{Mg}(\mathrm{II})$ and $\mathrm{Ca}(\mathrm{II})$.

\section{EXPERIMENTAL SECTION}

\section{Materials}

The disulfonato-silica hybrid was synthesized using 4-amino-5-hydroxy-naphtalene-2,7-disulfonic acid monosodium salt (ANSNa), sodium carbonate solution, chloroprophyltrimethoxysilane (CTS), rice hull ash, sodium hydroxide, hydrochloric acid, aquabidest. The metal cations were from magnesium nitrate hexahydrates $\left(\mathrm{Mg}\left(\mathrm{NO}_{3}\right)_{2} \cdot 6 \mathrm{H}_{2} \mathrm{O}\right)$ and calcium nitrate tetra hydrate $\left(\mathrm{Ca}\left(\mathrm{NO}_{3}\right)_{2} \cdot 4 \mathrm{H}_{2} \mathrm{O}\right)$. All other reagents unless silica, were of analytical reagent grade (Merck).

\section{Instrumentation}

A Flame atomic absorption spectrometer (Perkin Elmer 3110) was used for the determinations of metal ions. Infrared spectra were recorded on a Prestige-21 Shimadzu FT-IR apparatus. Morphology of DSSH was obtained from SEM-EDX (JSM 6360 LA). An Orion 4 Star digital $\mathrm{pH}$ meter was used for the $\mathrm{pH}$ adjustments.

\section{Procedure}

\section{Synthesis of disulfonato silica hybrid}

The disulfonato silica hybrid were prepared by suspending $8.125 \mathrm{~g}$ of ANSNa in $50 \mathrm{~mL}$ of sodium carbonate solution $0.05 \mathrm{M}$. Subsequently, $6 \mathrm{~mL}$ CTS was dropped to the suspension under constant stirring within $5 \mathrm{~h}$ at $60{ }^{\circ} \mathrm{C}$ [7]. Sodium silicate solution $100 \mathrm{~mL}$ and $3 \mathrm{M}$ of $\mathrm{HCl}$ solution was dropped to the suspension under constant stirring at $25{ }^{\circ} \mathrm{C}$ for $24 \mathrm{~h}$ until the gel was formed [9]. This gel was aged for $2 \mathrm{~h}$ at $70{ }^{\circ} \mathrm{C}$, dried in a vacuum for $24 \mathrm{~h}$. The gel was filtered and the residue was washed with aquabidest until neutral. The gel was dried at $60^{\circ} \mathrm{C}$ for $2 \mathrm{~h}$.

\section{Adsorption process}

Metal salt of $\mathrm{Mg}\left(\mathrm{NO}_{3}\right)_{2} \cdot 6 \mathrm{H}_{2} \mathrm{O}$ and $\mathrm{Ca}\left(\left(\mathrm{NO}_{3}\right)_{2} \cdot 4 \mathrm{H}_{2} \mathrm{O}\right.$ were used as the source of metal ions. $\mathrm{Mg}$ (II) and $\mathrm{Ca}$ (II) solutions $(1000 \mathrm{mg} / \mathrm{L})$ was prepared by dissolving appropriate amounts of metal salt in doubly distilled water. The working solution was prepared by diluting the stock solution to appropriate volumes.

All the adsorption experiments were conducted batchwise [10]; the sorption equilibrium was obtained by shaking $0.05 \mathrm{~g}$ of HDSS in $25 \mathrm{~mL}$ of aqueous solution containing magnesium ion for $2 \mathrm{~h}$. Adsorption experiments were carried out in an incubator at temperature of $25{ }^{\circ} \mathrm{C}$. After $2 \mathrm{~h}$ was shaked, the mixture was aged for $24 \mathrm{~h}$, solution was filtered and the magnesium ion concentrations in the aqueous solutions were measured. Initial and equilibrium magnesium ion concentrations in the aqueous solutions were determined by using flame atomic absorption spectrometer. Initial $\mathrm{pH}$ of the solutions was adjusted to the desired $\mathrm{pH}$ by adding nitric acid to the medium to maintain a constant $\mathrm{pH}$. Experiments were repeated three times in each case. The amount of adsorbed magnesium ion was calculated from the difference between metal concentration in the aqueous solution before and after equilibrium and the certain weight of the dry DSSH.

\section{RESULT AND DISCUSSION}

\section{Synthesis of HDSS}

The synthetic procedure was based on the production of the new sylilant agent named DSSH (Fig. 1) from the reaction between 4-amino-5-hydroxy naphtalene-2,7-disulfonic acid monosodium salt (ANSNa) and 3-chloropropyltrimethoxysilane ( $\mathrm{SiCl})$ according to Eq. (1). This reaction is analogue with the synthetic procedure of the reaction between 2mercaptothiazoline (MTZ) and 3-chloropropyltrimethoxy silane $(\mathrm{SiCl})$ to produce SiMTZ has reported by Evangelista, S.M., et al. [7]. The final silica modified with ANSNa was produced by ordered polymerization of Si-sulfonate, sodium silicate, and hydrochloric acid according to Eq. (2).

The sulphur content in DSSH obtained by destruction of DSSH was $26,482 \%(w / w)$. The data indicate that ANSNa has attached onto silica. From 


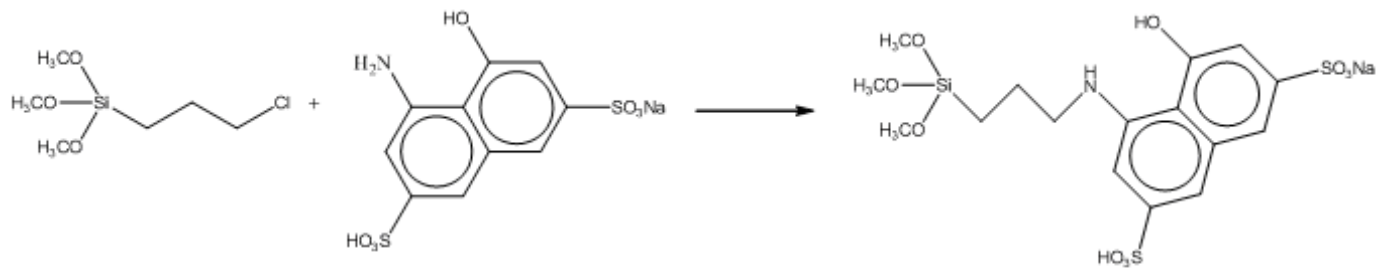

CTS

ANSNa
(1)

SiANSNa

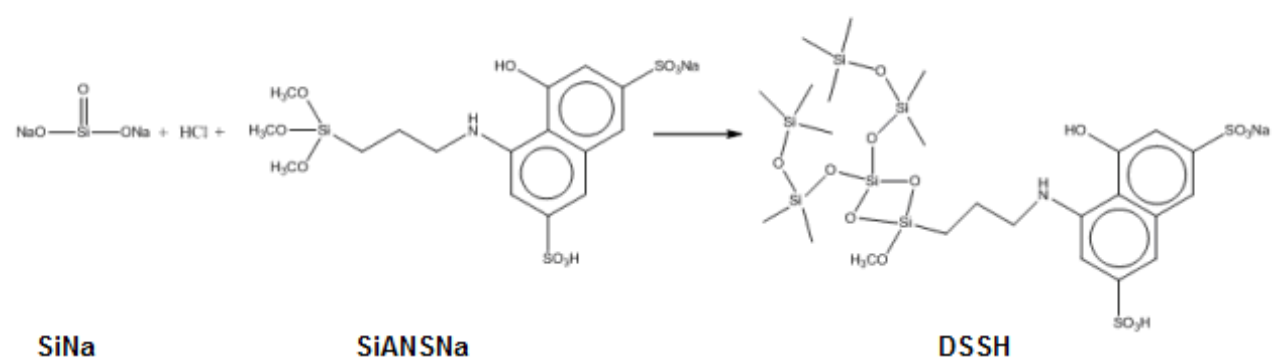

(2)

Fig 1. The reaction equation (1) between $\mathrm{ANSNa}$ and 3-chloropropyltrimethoxysilane (SiCl) to produce SiANSNa and (2) polymerization of Si-sulfonate, sodium silicate, and hydrochloric acid to produce DSSH

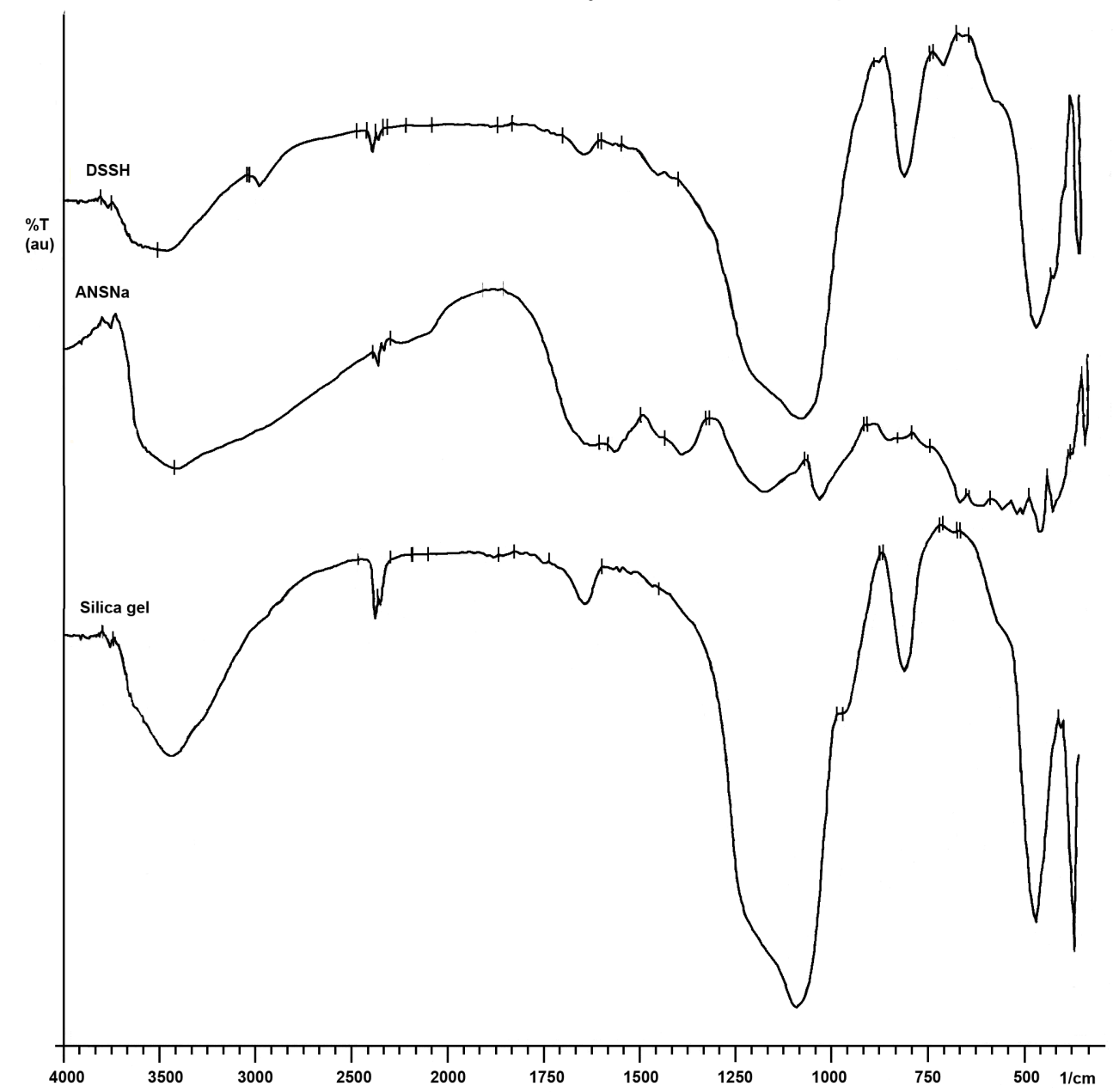

Fig. 2. Infrared spectra of solid samples silica: silica gel, ANSNa, and DSSH

infrared spectra (Fig. 2) obtained for solid samples, it was possible to conclude the successful of the ANSNa attachment onto silica gel due to the presence of two well-defined peaks at 2960 and $1543 \mathrm{~cm}^{-1}$ in DSSH 


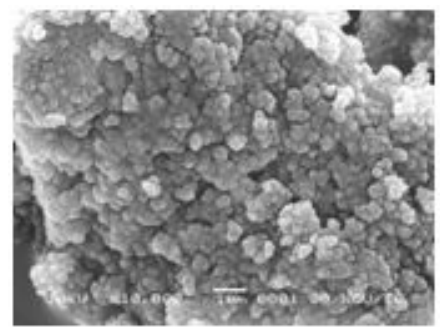

a. Silica gel

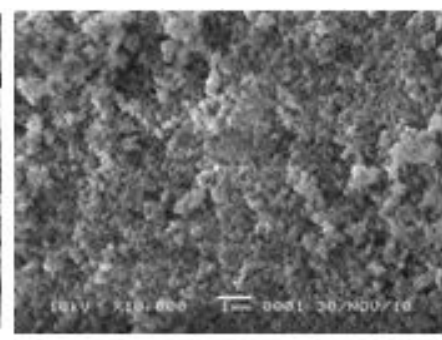

b. DSSH
Fig. 3. SEM images of (a) silica gel and (b) DSSH

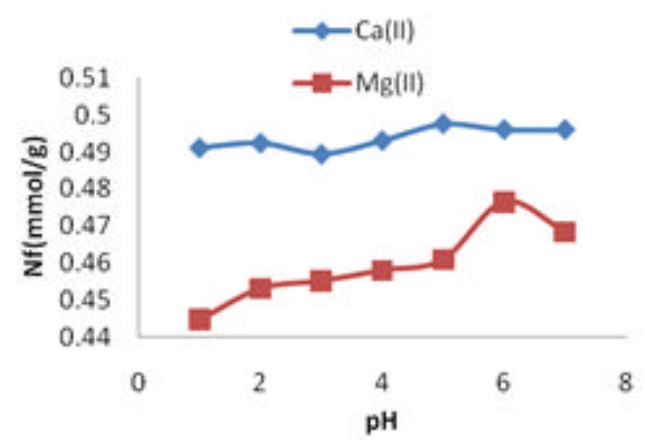

Fig. 4. The effect of $\mathrm{pH}$ on the sorption of $\mathrm{Mg}(\mathrm{II})$ and $\mathrm{Ca}(\mathrm{II})$ ions

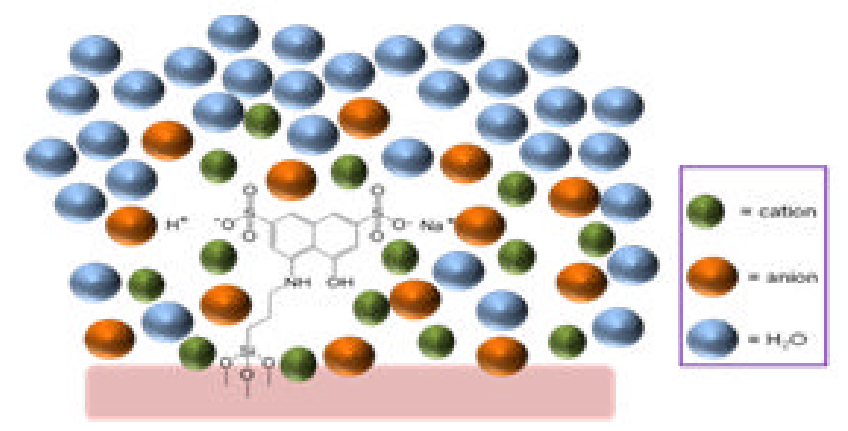

Fig 5. Proposed scheme of the interaction between DSSH and cation

spectrum. However, sulfonic acid peaks at $1028 \mathrm{~cm}^{-1}$, peaks at 1095 1085 $\mathrm{cm}^{-1}$ corresponding to symmetric C-S stretching vibrations, peaks at $960 \sim 950 \mathrm{~cm}^{-1}$ for asymmetric C-S stretching, and peaks at 1028, 1254, and $1084 \mathrm{~cm}^{-1}$ for $\mathrm{S}=\mathrm{O}$ stretching cannot be distinguished from the broad and strong siloxane absorption peak because of the overlapping of bands [11-12]. However, the silica hybrid, DSSH, presented a characteristic peak at $2962 \mathrm{~cm}^{-1}$ is assigned to $\mathrm{C}-\mathrm{H}$ stretching of $\mathrm{sp}^{3}$ carbon and confirm the presence of the organic group attached onto silica surface $[7,13]$. Absorption band at $3450 \mathrm{~cm}^{-1}$ was characteristic for $-\mathrm{OH}$. The overlap peaks at 3270 and $3100 \mathrm{~cm}^{-1}$ were characteristic for $\mathrm{N}-\mathrm{H}$ stretching and $\mathrm{N}-\mathrm{H}$ symmetric stretching, respectively [14]. The other absorption bands at $\mathrm{N}-\mathrm{C}$ stretching and $\mathrm{C}-\mathrm{H}$ asymmetric stretching were determined by peaks at 1543 and $2960 \mathrm{~cm}^{-1}$, respectively [14]

Fig. 3 is SEM image of silica gel and DSSH. SEM image of silica gel and DSSH showing the particulate structure of DSSH has a smaller size than silica gel. The binding of the sulfonate group in the sol gel silica gel will stop the formation of siloxane group, so the globule growth will be faster. Therefore, the size of the polymer particle becomes smaller.

\section{Effect of $\mathrm{pH}$}

The $\mathrm{pH}$ of solution is an important parameter in adsorption process because of the $\mathrm{pH}$ dependencies of the complexation reactions or electrostatic interaction in physisorption processes at the adsorption surface [9]. Variation of the magnesium uptake with $\mathrm{pH}$ has shown in Fig. 4. The capacities were found to be low at lower $\mathrm{pH}$ values and increase with increasing the $\mathrm{pH}$. This can be explained using competitive adsorption of $\mathrm{H}_{3} \mathrm{O}^{+}$ions and metal ions for the same active adsorption site. As the $\mathrm{pH}$ increased, the adsorption surfaces becomes less positive and therefore electrostatic attraction between the metal ions and DSSH surfaces is likely to increase. This also may be further explained with the sulfonate groups present on DSSH. At pH > 6, the capacity was found to decrease. This may be due to the formation of magnesium and calcium hydroxide. The optimum $\mathrm{pH}$ values at which the maximum metal uptake could be achieved, was obtained at $\mathrm{pH} 6.0$ for $\mathrm{Mg}(\mathrm{II})$ and $\mathrm{Ca}(\mathrm{II})$ ion. For all subsequent experiments, this optimum $\mathrm{pH}$ values was then used.

\section{Kinetic Studies}

The study of adsorption dynamic describes the solute uptake rate, and this rate controls the habitation time of adsorbate uptake at the solid-solution interface (Fig. 5). Chemical kinetics gives information about reaction pathways and times to reach equilibrium. Adsorption kinetics shows a large dependence on the physical and/or chemical characteristics of the sorbent material.

Numerous kinetic models have described the reaction order of adsorption system based on solution concentration [7]. In this study, batch sorption kinetics of $\mathrm{Mg}(\mathrm{II})$ ions with the HDSS have been studied in terms of first-order kinetic, second-order kinetic, pseudo-first-order kinetic, and pseudo-second-order models (Table 1). The pseudo-second order kinetics model is given in the following form [15-16]:

$\frac{t}{q_{t}}=\frac{1}{k_{2} q_{e}^{2}}+\frac{t}{q_{e}}$ 
Table 1. Adsorption kinetics models for $\mathrm{Mg}(\mathrm{II})$ and $\mathrm{Ca}(\mathrm{II})$ ions onto $\mathrm{DDSH}^{*}$

\begin{tabular}{lllll}
\hline Kinetics models & \multicolumn{2}{c}{$\mathrm{Mg}(\mathrm{II})$} & \multicolumn{2}{c}{$\mathrm{Ca}(\mathrm{II})$} \\
\cline { 2 - 5 } & Rate constant $(\mathrm{k})$ & $\mathrm{R}^{2}$ & Rate constant $(\mathrm{k})$ & $\mathrm{R}^{2}$ \\
\hline First order & $-0.004 \mathrm{~min}^{-1}$ & 0.922 & $-0.002 \mathrm{~min}^{-1}$ & 0.955 \\
Second order & $0.000 \mathrm{~min}^{-1}$ & 0.949 & $2 \times 10^{-5} \mathrm{~min}^{-1}$ & 0.965 \\
Pseudo-first order & $0.000 \mathrm{~min}^{-1}$ & 0.879 & $-0.002 \mathrm{~min}^{-1}$ & 0.970 \\
Pseudo-second order & $1.099 \mathrm{~min}^{-1}$ & 0.992 & $0.059 \mathrm{~min}^{-1}$ & 0.998 \\
\hline *at $\mathrm{C}_{0}=20 \mathrm{mg} / \mathrm{L}, \mathrm{pH}$ 6.0; $\mathrm{DSSH}=0.05 \mathrm{~g}$; temperature $25^{\circ} \mathrm{C}$ & &
\end{tabular}

Table 2. Adsorption isotherm models for $\mathrm{Mg}(\mathrm{II})$ and $\mathrm{Ca}$ (II) ions onto DSSH

\begin{tabular}{clll}
\hline \multicolumn{2}{c}{ Parameter } & $\mathrm{Mg}(\mathrm{II})$ & $\mathrm{Ca}(\mathrm{II})$ \\
\hline & $\mathrm{q}_{\mathrm{m}}(\mathrm{mmol} / \mathrm{g})$ & 0.084 & 0.144 \\
Langmuir parameter & $\mathrm{K}_{\mathrm{a}}\left(\mathrm{x} 10^{4} \mathrm{mg} / \mathrm{g}\right)$ & 1.156 & 0.917 \\
& $\Delta \mathrm{G}^{\circ}(\mathrm{kJ} / \mathrm{mol})$ & -23.3 & -22.8 \\
& $\mathrm{R}^{2}$ & 0.998 & 0.984 \\
\hline \multirow{3}{*}{ Freundlich parameter } & $\mathrm{N}(\mathrm{mmol} / \mathrm{g})$ & 2.632 & 1.855 \\
& $\mathrm{~K}_{\mathrm{F}}(\mathrm{mg} / \mathrm{g})$ & 0.608 & 1.002 \\
& $\mathrm{R}^{2}$ & 0.909 & 0.971 \\
\hline
\end{tabular}

where $k_{2}$ is the rate constant for pseudo-second-order reaction $\left(\mathrm{gmg}^{-1} \mathrm{~min}^{-1}\right), q_{e}$ and $q_{t}$ are the amounts of solute adsorbed at equilibrium and any time $\left(\mathrm{mgg}^{-1}\right)$, respectively. The straight line plots of $t / q_{t}$ versus $t$ are used to obtain the constants for pseudo-second-order reaction. Herein, the initial sorption rate is

$\mathrm{k}_{\mathrm{o}}=\mathrm{k}_{2} \mathrm{q}_{\mathrm{e}}^{2}$

The greatest values of correlation factor $R^{2}$, obtained from the plots of pseudo-second-order kinetics given in Table 1. These results indicated that the adsorption of $\mathrm{Mg}(\mathrm{II})$ ions onto DSSH follows well the pseudo-second order kinetics model. The pseudosecond-order rate expression was used to describe chemisorptions involving valency forces through the sharing or exchange of electrons between the adsorbent and adsorbate as covalent forces, and ion exchange [17]. In recent years, the pseudo-second-order rate expression has been widely applied to the adsorption of pollutants from aqueous solutions [17].

\section{Thermodynamic Studies}

The analysis of the isotherm data is important to develop an equation which accurately represents the results and could be used for design purposes. In order to investigate the adsorption isotherm, two equilibrium isotherms were analyzed: Langmuir and Freundlich.

The constant parameters of the isotherm equation for this adsorption processes were calculated by linear regression of isotherm equations. The constant parameters and correlation coefficients $\left(R^{2}\right)$ are summarized in Table 2.

The Langmuir adsorption isotherm has been successfully applied to many real sorption processes. It predicts the maximum monolayer adsorption capacity of the adsorbent and also determines whether the adsorption is favorable or not. The linear Langmuir isotherm is represented by following equation [18-20]:

$\frac{\mathrm{C}_{\mathrm{e}}}{\mathrm{q}_{\mathrm{e}}}=\frac{1}{\mathrm{q}_{0} \mathrm{~K}}+\frac{\mathrm{C}_{\mathrm{e}}}{\mathrm{q}_{0}}$

where $C_{e}$ is the solute concentration at equilibrium $(\mathrm{mg} / \mathrm{L}), q_{0}$ the maximum adsorption capacity $(\mathrm{mg} / \mathrm{g})$, and $K$ is the adsorption equilibrium constant $(\mathrm{L} / \mathrm{mg})$. The Langmuir $\left(C_{e} / q_{e}\right.$ versus $\left.C_{e}\right)$ plots of $\mathrm{Mg}$ (II) were found to be linear for the whole concentration range studied and the correlation coefficients were extremely high. The maximum adsorption capacities were determined as $0.084 \mathrm{mmol} / \mathrm{g}$ and $0.144 \mathrm{mmol} / \mathrm{g}$ for $\mathrm{Mg}(\mathrm{II})$ and $\mathrm{Ca}(\mathrm{II})$, respectively (Table 2).

The Freundlich isotherm is the earliest known relationship describing the adsorption isotherm [21]. This fairly satisfactory empirical isotherm can be used in adsorption from dilute solutions. The ordinary adsorption isotherm is expressed by the following equation:

$$
\mathrm{q}_{\mathrm{e}}=\mathrm{K}_{\mathrm{F}} \mathrm{C}_{\mathrm{e}}^{1 / n}
$$

where $C_{e}$ is the equilibrium concentration in the solution $(\mathrm{mg} / \mathrm{L}), q_{e}$ the equilibrium adsorption capacity $(\mathrm{mg} / \mathrm{g})$, and $K_{F}$ and $1 / n$ are empirical constants.

The Langmuir and Freundlich isotherms constants are shown in Table 2.

Thermodynamic considerations of an adsorption process are necessary to conclude whether the process is spontaneous or not. The Gibbs free energy change, $\Delta G^{\circ}$, is an indication of spontaneity of a chemical reaction and therefore is an important criterion for spontaneity. Reaction occurs spontaneously at a given temperature if $\Delta G^{\circ}$ is a negative quantity. The free energy of an adsorption, calculating based on the adsorption equilibrium constant $K_{a}$ is given by the following Gibbs equation [18] 
$\Delta G^{\circ}=-R T \ln K_{a}$

where $\Delta G^{\circ}$ is the standard free energy change $(\mathrm{J} / \mathrm{mol}), R$ the universal gas constant $(8.314 \mathrm{~J} / \mathrm{molK})$, and $\mathrm{T}$ is the absolute temperature $(\mathrm{K})$.

The parameter $\Delta G^{\circ}$ for the adsorption process using the $K_{a}$ from the Langmuir isotherm is shown in Table 1. The $\Delta G^{\circ}$ calculated gives negative value for adsorption of $\mathrm{Mg}(\mathrm{II})$ and $\mathrm{Ca}(\mathrm{II})$ onto $\mathrm{DSSH}$, confirm the feasibility of the process and the spontaneous nature of the adsorption.

\section{CONCLUSION}

The DSSH can be used to adsorb magnesium and calcium ions from the aqueous solution. The kinetics of adsorption processes fit to a pseudo-second-order kinetic model. Thermodynamic parameter, $\Delta \mathrm{G}^{\circ}$ has been evaluated from adsorption equilibrium constant based on a Langmuir isotherm model. The negative values of $\Delta \mathrm{G}^{\circ}$ indicate the spontaneous nature of adsorption $\mathrm{Mg}(\mathrm{II})$ and $\mathrm{Ca}(\mathrm{II})$ onto HDSS, suggesting a high preference of $\mathrm{Mg}(\mathrm{II})$ and $\mathrm{Ca}(\mathrm{II})$ onto DSSH.

\section{ACKNOWLEDGEMENT}

This study was supported in part by 'Hibah Doktor' Program, Directorate General Higher Education, Ministry of National Education the Republic of Indonesia, 2009.

\section{REFERENCES}

1. Contreras, C., Rosa, G.D.L., Videa, J.R.P., and Torresdey, J.L.G., 2006. J. Hazard. Mater., 133, 1-3, 79-84.

2. Petrucci, R.H., 1985, General Chemistry, Principles and Modern Application, $4^{\text {th }}$ ed., Collier Macmillan. Inc.

3. Azmiyawati, C., Nuryono, and Narsito, 2005, Indo. J. Chem., 5, 1, 31-35.
4. Hofen, K., Weber, S., Chan, C.P.C., and Majewski, P., 2011, Appl. Surf. Sci., 257, 9, 2576-2580.

5. Aylward, W.M., and Pickup, P.G., 2008, Electrochim. Acta, 53, 11, 3897-3902.

6. Ma, J-Z., Hu, J., and Zhang, Z-J., 2007, Eur. Polym. J., 43, 4169-4177.

7. Evangelista, S.M., Deoliviera, E., Castro, G.R., Zara, L.F., and Prado, A.G.S., 2007, Surf. Sci., 601, 10, 2194-2202.

8. Das, B., Suneel, K., Venkateswarlu, K., and Ravikanth, B., 2008, Chem. Pharm. Bull., 56, 3, 366-368.

9. Kamath, S.R., and Proctor, A., 1997, Arkansas Rice Research Studies.

10. Ünlu, N., and Ersoz, M., 2006, J. Hazard. Mater., 136, 2, 272-280.

11. Oh, Y-K., Hong, L-Y., Asthana, Y., and Kim, D-P., 2006, J. Ind. Eng. Chem., 12, 6, 911-917.

12. Troitsky, V., Berzina, T., Shchukin, D., Sukhorukov, G., Erokhin, V., and Fontana, M.P., 2004, Colloids Surf., A, 245, 1-3, 163-168.

13. Prado, A.G.S., Sales, J.A.A., Carvalho, R.M., Rubim, J.C., and Airoldi, C., 2004, J. Non-Cryst. Solids, 333, 1, 61-67.

14. Günzler, H., and Gremlich, H-U., 2002, IR Spectroscopy an Introduction, Wiley-VCH, Weinheim.

15. Ho, Y.S., and Mackay, G., 1999, Process Biochem., 34, 451-465.

16. Hameed, B.H., Din, A.T.M., and Ahmad, A.L., 2007, J. Hazard. Mater., 141, 3, 819-825.

17. Ho, Y.S., 2006, J. Hazard. Mater., 136, 3, 681-689.

18. Langmuir, I., 1918, J. Am. Chem. Soc., 40, 9, 1361-1403.

19. Ho, Y.S., Huang, C.T., and Huang, H.W., 2002, Process. Biochem., 37, 12, 1421-1430.

20. Kul, A.R., and Koyuncu, H., 2010, J. Hazard. Mater., 179, 1-3, 332-339.

21. Freundlich, H.M.F., 1906, Z. Phys. Chem., 57A, 385-470. 